\title{
Sugar maple, black spruce and tamarack do not reproduce vegetatively from roots
}

\author{
by David C. F. Fayle ${ }^{1}$
}

Recent silvical literature on sugar maple (Acer saccharum Marsh.), black spruce [Picea mariana (Mill.) B.S.P.] and tamarack [Larix laricina (Du Roi) K. Koch], [also European black alder (Alnus glutinosa (L.) Gaertn.) and boxelder [Acer negundo L.)] continues to refer, erroneously, to their reputed ability to reproduce vegetatively from root material. This error is the result of improper identification in the first place, subsequent uncritical evaluation, use of secondary rather than the original reference and reluctance to reject what is "in the literature".

Key words: vegetative reproduction, root suckers, sugar maple, black spruce, tamarack, boxelder, European black alder

\begin{abstract}
La littérature sylvicole récente sur l'érable à sucre (Acer saccharum Marsh.), l'épinette noire (Picea mariana (Mill.) B.S.P.) et le mélèze (Larix laricina (Du Roi) K. Koch), (ainsi que sur l'aulne noir (Alnus glutinosa (L.) Gaertn.) et l'érable à Giguère (Acer negundo L.)) continue de faire référence, de façon erronée, à leur capacité réputée de se propager végétativement par le matériel racinaire. Cette erreur provient d'une identification inadéquat en premier lieu, d'une évaluation subséquente non discriminative, de l'utilisation de références secondaires plutôt qu'originales et la réticence à rejeter ce qu'on retrouve "dans la littérature".
\end{abstract}

Mots clés: reproduction végétative, drageons, érable à sucre, épinette noire, mélèze, érable à Giguère, aulne noir d'Europe

\begin{abstract}
"The title of a paper is a label. It is not a sentence...inclusion of [the present tense] results in a title that now seems to be a loud assertion. It has a dogmatic ring to it..." (Day 1988).
\end{abstract}

\section{Introduction}

Like Day, I too have misgivings about titles that are a sentence, but since the title is all that may be read and I wish to make an assertion, I have suppressed my dislike. I want to bury the notion that sugar maple (Acer saccharum Marsh.), black spruce [Picea mariana (Mill.) B.S.P. and tamarack (Larix laricina (Du Roi) K. Koch] can reproduce vegetatively from root tissue. No unequivocal evidence for such vegetative reproduction has been reported. Nonetheless, this notion persists in Canadian and United States' literature on silvical information (Arnup et al. 1988; Anderson et al. 1990; Burns and Honkala 1990a,b). However, as I will argue, the original statements were the result of mistaken identification about the origin of the vegetative regeneration because conclusions were based on the external appearance of material without anatomical verification. Where the latter was done, the origin was shown to be stem (branch) material, i.e., layering had occurred. Persistence in the notion may be the result of uncritical evaluation of the literature, compounded in some instances by use of a secondary reference rather than the original source, scientific politeness and reluctance to reject 'literature'. The same also appears to apply to two other species: European black alder [Alnus glutinosa (L.) Gaertn.] and boxelder or Manitoba maple (Acer negundo L.).

\footnotetext{
${ }^{1}$ Formerly Silviculture Professor, Faculty of Forestry, University of Toronto. Current address: R.R. \#1, Palgrave, Ontario, Canada LON 1 P0.
}

\section{Sugar Maple}

I will start with sugar maple because of my direct experience. In their description in the Silvics of North America of the vegetative reproduction characteristics of this species, Godman et al. (1990) stated that "Sugar maple reproduces by stump sprouts and will occasionally layer (22). Root suckering is rare." The earlier Silvics of Forest Trees of the United States (Fowells 1965) had "Sugar maple reproduces by means of stump sprouts and, to some extent, by root suckers". Fowells is also the primary implicit reference used by Anderson et al. (1990) but layering is also mentioned: "Reproduces easily by stump sprouts, and occasionally by root suckers or layerings."

Curiously, neither Godman et al. (1990) nor Fowells (1965) gave a reference for root suckering, but in $1962 \mathrm{I} \mathrm{had} \mathrm{inquired}$ about the basis of a similar statement in Godman (1957) that "Sugar maple reproduces vegetatively by means of stump sprouts and to some extent by root suckers." The response (personal communication from M.B. Dickerman, USDA Forest Service, St. Paul, Minnesota, 17 October 1962) stated that it was "based primarily on observations made at our Marquette, Michigan Field Unit. We have noted only two references to suckering in sugar maple in the library material available to us. Baker [1934], in "Theory and Practice of Silviculture" states that sugar maples "rarely send out root suckers"; Arbogast [1956] in "Basic Principles of Forest Management in Northern Hardwoods" refers to suckering in sugar maple. His observations are based on work of this Station. He has colored slides showing sugar maple suckers... . In later work at the same locality, Church observed several examples of root suckers at 
distances of 10 to 15 feet from sugar maple trees." In response to a request from me to see the slides, Arbogast (personal communication, February 26, 1963) loaned the slides and wrote: "We traced the sprouts back to nearby stumps and after examining the gross characteristics of the material concluded that they arose from roots." In 1962 I did not check Baker (1934) but did this time. In fact he did not refer specifically to sugar maple, only to maple: "Oaks, beech, ash, maple, alder, and willows rarely send out root suckers."

As I wrote in reference 22 cited above (Fayle 1964), based on my own investigations in Ontario, "what appeared to be [root] suckers were stems which had grown from natural layering. Examples are given...to show how some stems could be mistaken for sucker origin, and to demonstrate the propensity of maple to layer from a variety of sources - seedlings, branches, basal sprouts and trees." I included written and photographic documentation with anatomical evidence of the stem material origin (presence of pith and paired, opposite buds) whereas none is provided elsewhere.

\section{Black Spruce}

Neither Sims et al. (1990) nor Bell (1991) mentioned that black spruce might reproduce vegetatively from roots. However, Viereck and Johnston (1990) stated that "black spruce may reproduce from shoots originating from roots (12), but this is uncommon". The reference number is to Fowells (1965), in which it is noted that a "form of vegetative reproduction called 'rooting' has been reported in black spruce (35, 45 )" but cautions that "Rootlings are said to originate from nearsurface roots that produce adventitious vegetative buds....Similar cases investigated in Minnesota and Ontario were found to be true layers...(67) ${ }^{15}$ " The respective references are to Horton and Lees (1961), LeBlanc (1955) and Stanek (1961), with the footnote at the end of the quotation to Heinselman (1961).

The original perpetrator of the rooting or rootling idea was LeBlanc and the notion was given a further boost by Horton and Lees. LeBlanc used "rooting" throughout his article, calling it "more a descriptive word than a scientific term", and suggests that "Probably botanists or plant anatomists will be in a better position to give it a proper name." (Yes. Layering. In an accompanying Note the editor suggests "rootling" as a possible noun that would correspond with "seedling", and comments that the author agrees.) LeBlanc actually credited Hosie (1954) as intimating that black spruce can reproduce from living roots, but this arose from a misinterpretation by LeBlanc. Although Hosie (1954) wrote, perhaps ambiguously, that "poplar, birch, black spruce or balsam...can reproduce from living roots or branches", it is quite clear later in Hosie's article that reproduction from roots does not apply to black spruce. First: "We must depend then on whatever conifer advance growth survives the logging and on other growth that arises from living roots of trees and shrubs that can reproduce in that way, such as poplar, white birch, willow, maple, hazel, raspberry and others" - though Hosie is wrong here; only poplar and raspberry can do so. And secondly "black spruce...has the habit of producing new growth by layering, that is, from rooted branches."2

\footnotetext{
${ }^{2}$ Professor Hosie was incensed at leaming of LeBlanc's attribution (K.A. Armson, personal communication, September 1995), but apparently did not correct the misinterpretation.
}

LeBlanc (1955) implied in the statement of a "root shooting up into a young tree" that a root apex could convert into a shoot apex, but he did not provide any anatomical evidence. Horton and Lees (1961) described rootings as "simply roots or root sprouts which shoot upwards". The implication in Fowells, as quoted earlier, is that LeBlanc thought rootlings were "from near-surface roots that produce adventitious vegetative buds." But LeBlanc's only mention of adventitious buds was black spruce's "capacity to grow adventitious buds on its stem, which can develop into a thrifty branch".

Amup et al. (1988) described both layering and rooting/rootling as vegetative reproduction forms in black spruce, citing Horton and Lees (1961) for the latter form, whereas Sims et al. (1990) and Bell (1991) referred only to layering.

In contrast to the absence of internal, anatomical verification provided by LeBlanc (1955) and Horton and Lees (1961), Stanek (1961) carefully documented in words and photomicrographs the branch origin of those layers "which had a surprising likeness to roots". Although appearing root-like externally, cross sections showed the presence internally of a central pith, i.e., branch tissue, rather than the diarch primary xylem between two resin canals of a root.

\section{Tamarack}

With tamarack, according to Johnston (1990), "Roots are also known to produce shoots (12)." The reference is again to Fowells (1965) where there is the statement: "Roots are known to produce shoots. In Alberta it was reported that 11 sprouts about a foot tall were attached at various points along a 32-foot root (24)." This reference, in turn, is to Lewis et al. (1928) who commented on the tendency for a linear arrangement of larch stems on bogs, and of their roots which run from tree to tree and form "slightly raised ridges" or "banks...(that) rise about 18 inches $(46 \mathrm{~cm}$.) above the intervening open spaces". They described, however, one case where "several individual seedling larch trees arose from one long root, no less than 11 seedlings about $1 \mathrm{ft}$. $(30 \mathrm{~cm}$.) high having developed at various points from a root $32 \mathrm{ft}$. (975 cm.) in length." No photographs or anatomical descriptions were provided of this phenomenon. Although they searched for another example, excavating and photographing roots and finding "numerous cases of root fusion", they were unsuccessful. Thus the case they described is probably layering.

\section{Other Species}

Funk (1990) stated that "Root suckers are rare (60)" in European black alder. His reference is to McVean (1955) who uses exactly the same words but referenced Loudon (1875). I have not obtained a copy of the latter to determine the verification for the statement, but doubt if anatomical evidence is included.

Lastly, in Manitoba maple or boxelder (Acer negundo L.), according to Overton (1990), "Reproduction by stump and root sprouts is common...from young, vigorous trees $(8,18)$." The first reference is to Eyre (1980), in which I could find no comparable statement, and the second is to Maeglin and Ohmann (1973) who stated "Asexual reproduction by sprout and suckering is common in boxelder, especially in the case of young vigorous trees (Green 1934)." And what did Green have to say? Only that "This species coppices fairly well, especially from young trees"! 


\section{A Hope}

By not perhaps being scientifically polite, my hope is that future silvical references to sugar maple, black spruce and tamarack, and to European black alder and boxelder, will not mention purported ability to reproduce vegetatively from root material, or that the statement will be in the negative. I would also hope that my exposition here will emphasize the dangers in not returning to the original source of a statement.

But I have my doubts about the burial of the notion. Exhumation will occur; there's a sucker born every minute; and besides, it's in the literature...!

\section{Acknowledgements}

My thanks to Jim Rice and Ken Farr who obtained copies of some references for me, and to several reviewers, one of whom cautioned that the "veracity of an assertion is not determined by the loudness with which it is made!".

\section{References}

Anderson, H.W., B.D. Batchelor, C.M. Corbett, A.S. Corlett, D.T. Duego, C.F. Husk and W.R. Wislon. 1990. A silvicultural guide for the Tolerant Hardwoods Working Group in Ontario. Ontario Ministry of Natural Resources, Science and Technology Series, Volume 7. $178 \mathrm{pp}$

Arbogast, C., Jr. 1956. Basic principles of forest management in northern hardwoods. Northern Hemlock and Hardwood Manufacturers Association, Land O'Lakes, Wisconsin. (Original not seen.)

Arnup, R.W., B.A. Campbell, R.P. Raper, M.F. Squires, K.D. Virgo, V.H. Wearn and R.G. White. 1988. A silvicultural guide for the Spruce Working Group in Ontario. Ontario Ministry of Natural Resources, Science and Technology Series, Volume 4. 100 pp.

Baker, F.S. 1934. Theory and practice of silviculture. McGraw-Hill, New York.

Bell, F.W. 1991. Critical silvics of conifer crop species and selected competitive vegetation in Northwestern Ontario. Forestry Canada, Ontario Region/ Northwestem Ontario Forest Technology Development Unit, Ontario Ministry of Natural Resources. COFRDA Report 3310/NWOFTDU Technical Report 19.177 pp.

Burns, R.M. and B.H. Honkala (Technical coordinators). 1990a. Silvics of North America. Volume 1. Conifers. United States Department of Agriculture, Forest Service. Agricultural Handbook $654.674 \mathrm{pp}$.

Burns, R.M. and B.H. Honkala (Technical coordinators). 1990b. Silvics of North America. Volume 2. Hardwoods. United States Department of Agriculture, Forest Service. Agricultural Handbook $654.877 \mathrm{pp}$.

Day, R.A. 1988. How to write and publish a scientific paper. 3rd edition. The Oryx Press, Phoenix, AZ. 211 pp.

Eyre, F.H. (ed.). 1980. Forest cover types of the United States and Canada. Society of American Foresters, Washington, DC. 148 pp. Fayle, D.C.F. 1964. Layering habit of sugar maple. For. Chron. 40: $116-121$.

Fowells, H.A. (Compiler). 1965. Silvics of forest trees of the United States. United States Department of Agriculture, Forest Service. Agricultural Handbook 271. 762 pp.
Funk, D.T. 1990. Alnus glutinosa (L.) Gaertn. European alder. pp. 105-115 In R.M. Burns and B.H. Honkala (Technical coordinators). Silvics of North America. Volume 2. Hardwoods. United States Department of Agriculture, Forest Service. Agricultural Handbook 654.

Godman, R.M. 1957. Silvical characteristics of sugar maple. United States Department of Agriculture, Forest Service, Lake States Forest Experiment Station, Station Paper 50. 24 pp.

Godman, R.M., H.W. Yawney and C.H. Tubbs. 1990. Acer saccharum Marsh. Sugar maple. pp. 78-91 In R.M. Burns and B.H. Honkala (Technical coordinators). Silvics of North America. Volume 2. Hardwoods. United States Department of Agriculture, Forest Service. Agricultural Handbook 654.

Green, G.R. 1934. Trees of North America (exclusive of Mexico). Volume II - The broadleaves. Edwards Brothers, Inc., Ann Arbor, MI. 344 pp.

Heinselman, M.L. 1961. Black spruce on the peatlands of former glacial Lake Agassiz and adjacent areas in Minnesota: a study of forest sites, bog processes, and bog types. University of Minnesota, Ph.D. thesis. 331 pp. (Original not seen.)

Horton, K.W. and J.C. Lees. 1961. Black spruce in the foothills of Alberta. Canada Department of Forestry, Forest Research Branch Technical Note 110. 54 pp.

Hosie, R.C. 1954. The regeneration of cut-over areas. For. Chron. 30: $128-130$.

Johnston, W.F. 1990. Larix laricna (Du Roi) K. Koch. Tamarack. pp. 141-151 In R.M. Burns and B.H. Honkala (Technical coordinators). Silvics of North America. Volume 1. Conifers. United States Department of Agriculture, Forest Service. Agricultural Handbook 654.

LeBlanc, J.-H. 1955. A mode of vegetative propogation in black spruce. Pulp and Paper Magazine of Canada. 56: 146-153.

Lewis, F.J., E.S. Dowding and E.H. Moss. 1928. The vegetation of Alberta II. The swamp, moor and bog vegetation of central Alberta. J. Ecol. 6: 19-70.

Loudon, J.C. 1875. Trees and shrubs of Britain. London. (Original not seen.)

McVean, D.N. 1955. Biological flora of the British Isles: Alnus lutinosa (L.) Gaertn. (A. rotundifolia Stokes). J. Ecol. 41: 447-466.

Maeglin, R.R. and L.F. Ohmann. 1973. Boxelder (Acer negundo): a review and commentary. Bull. Torrey Bot. Club 100: 357-363.

Overton, R.P. 1990. Acer negundo L. Boxelder. pp. 41-45 In R.M. Burns and B.H. Honkala (Technical coordinators). Silvics of North America. Volume 2. Hardwoods. United States Department of Agriculture, Forest Service. Agricultural Handbook 654.

Sims, R.A., H.M. Kershaw and G.M. Wickware. 1990. The autecology of major tree species in the North Central Region of Ontario. Forestry Canada, Ontario Region/Northwestern Ontario Forest Technology Development Unit, Ontario Ministry of Natural Resources. COFRDA Report 3302/NWOFTDU Technical Report 48. 126 pp. Stanek, W.K.L. 1961. Natural layering of black spruce in northern Ontario. For. Chron. 37: 245-258.

Viereck, L.A. and W.F. Johnston. 1990. Picea mariana (MIll.) B.S.P. Black spruce. pp. 227-237 In R.M. Burns and B.H. Honkala (Technical coordinators). Silvics of North America. Volume 1. United States Department of Agriculture, Forest Service. Agricultural Handbook 654. 